\title{
Changes in the facial soft tissue profile after maxillary orthognathic surgery
}

\author{
S. Rupperti' · P. Winterhalder ${ }^{2}$. S. Krennmair ${ }^{1}$. S. Holberg ${ }^{1}$. C. Holberg ${ }^{1}$ - G. Mast ${ }^{3}$. I. Rudzki ${ }^{1}$
}

Received: 8 July 2020 / Accepted: 8 March 2021 / Published online: 21 April 2021

(c) The Author(s) 2021

\begin{abstract}
Objectives To compare the changes of the soft tissue profile in relation to the displacement of the underlying hard structures in maxillary orthognathic surgery and to contribute to the esthetic prediction of the facial profile after surgical procedures.

Materials and methods We analyzed the sagittal changes in the facial soft tissue profile related to surgical changes in skeletal structures after maxillary osteotomy in a retrospective study. The study sample comprised 115 adult patients between the ages of 18-50 years who had undergone maxillary orthognathic surgery and interdisciplinary orthodontic treatment at the Department of Orthodontics, Ludwig-Maximilians University of Munich, Germany. LeFort I osteotomy cases in both maxillary monognathic and bignathic osteotomy procedures were included. All subjects had received rigid fixation. A cephalometric analysis of presurgical and postsurgical cephalograms was performed and the correlations between hard tissue and soft tissue change ratios were evaluated using a bivariate linear regression analysis. A vertical line through the landmark sella (S) perpendicular to the nasion-sella line (NSL) served as the reference plane.

Results The subnasale ( $\mathrm{Sn}$ ) followed the A point (A) by 57\%, the soft tissue A point (A') followed the A point (A) by $73 \%$ and the upper lip, represented by the landmark labrale superius (Ls) followed the upper incisor (Is) by 73\%; all three in a linear correlation with a mean prediction error of nearly $2 \mathrm{~mm}$.

Conclusion The scatterplots show a linear correlation with a wide spread for all three pairs of reference points. The wide spread and the high prediction error of almost $2 \mathrm{~mm}$ indicate low predictability of the expected lip position and Sn.
\end{abstract}

Keywords Cephalometry $\cdot$ Maxillary osteotomy $\cdot$ Esthetics $\cdot$ Orthognathic surgical procedures $\cdot$ Treatment outcome, prediction

\section{Veränderungen des fazialen Weichgewebeprofils nach maxillärer orthognather Chirurgie}

\section{Zusammenfassung}

Ziele Die Veränderungen des Weichgewebeprofils in Relation zur Verlagerung der darunter liegenden Hartgewebe durch maxilläre orthognathe Chirurgie zu vergleichen und einen Beitrag zur ästhetischen Prognose des Gesichtsprofils nach chirurgischen Maßnahmen zu leisten.

S. Rupperti

S.Rupperti@campus.lmu.de

1 Department of Orthodontics, Ludwig-Maximilians University of Munich, Munich, Germany
2 Department of Oral and Maxillofacial Surgery, RWTH Aachen, Aachen, Germany

3 Department of Oral and Maxillofacial Surgery, Ludwig-Maximilians University of Munich, Munich, Germany 
Material und Methode In einer retrospektiven Studie analysierten wir die sagittalen Veränderungen des fazialen Weichgewebeprofils in Beziehung zu den chirurgischen Veränderungen der skelettalen Strukturen nach maxillärer Osteotomie. Die Studienprobe besteht aus 115 erwachsenen Patienten im Alter von 18-50 Jahren, die sich interdisziplinär maxillärer orthognather Chirurgie und kieferorthopädischer Therapie an der Poliklinik für Kieferorthopädie der Ludwig-Maximilians-Universität München unterzogen hatten. LeFort-I-Osteotomie-Fälle sowohl maxillärer monognather als auch bignather Osteotomieverfahren wurden in die Studie aufgenommen. Alle Patienten hatten eine starre Fixierung erhalten. Es wurde eine kephalometrische Analyse von präoperativen und postoperativen Fernröntgenseitenbildern durchgeführt, die Korrelationen zwischen Hart- und Weichgewebeveränderungen wurden mittels einer bivariaten linearen Regressionsanalyse ausgewertet. Als Referenzebene diente eine vertikale Linie durch den Referenzpunkt Sella (S), rechtwinklig zur Nasion-Sella-Linie (NSL).

Ergebnisse Der Punkt Subnasale (Sn) folgte dem A-Punkt (A) um 57\%, der Weichgewebe-A-Punkt (A') folgte dem A-Punkt (A) um 73\%, und die Oberlippe, repräsentiert durch den Referenzpunkt Labrale superius (Ls), folgte dem Inzision superius (Is) um 73\%, alle 3 in einer linearen Korrelation bei einer mittleren Abweichung von fast 2 mm.

Fazit Die Punktdiagramme zeigen eine lineare Korrelation mit einer breiten Streuung aller 3 Referenzpunktpaare. Die breite Streuung und die hohe mittlere Abweichung von fast $2 \mathrm{~mm}$ lassen auf eine schwache Vorhersagbarkeit der zu erwartenden Position von Oberlippe und Sn schließen.

Schlüsselwörter Kephalometrie · Maxilläre Osteotomie · Ästhetik · Kieferorthopädische chirurgische Eingriffe Behandlungsergebnis, Vorhersage

\section{Introduction}

Orthognathic surgery is the treatment of choice for severe skeletal dysgnathia and dentofacial deformities. The surgical discipline, which began in 1849 in the USA, has evolved progressively in central Europe since the 1950s and today is commonly applied [29]. Although most patients benefit from surgery [20, 23], up to $22 \%$ are dissatisfied with the esthetic result [10]. The esthetic improvement of the facial profile very much affects the social and psychological well-being of the patient $[3,9,10]$. Prediction of the soft tissue profile is of great importance in treatment planning and patient motivation [16].

The first studies analyzing the soft tissue profile change after orthognathic surgery were published in the 1970s with the purpose to acquire more information that can be used as an esthetic guide in orthognathic surgery [18, 21, 25].

We included 115 maxillary LeFort I osteotomy cases in monognathic and bignathic procedures in this study. Our target was a contribution to the facial profile prediction after maxillary orthognathic surgery by providing profound data of the soft to hard tissue dependencies.

\section{Materials and methods}

In this retrospective study, we analyzed 115 patients on whom interdisciplinary orthodontic and orthognathic surgical treatment had been performed at the Department of Orthodontics and the Department of Oral and Maxillofacial Surgery, Ludwig-Maximilians University of Munich, Germany (Table 1).
The sample consists of 43 class II and 72 class III patients, all interbasal open $\mathrm{O} 1$ and $\mathrm{N} 1$ types with divergent inclination of the skeletal bases, with posterior inclination of the mandible and anterior inclination of the maxilla in various manifestations.

On all 115 subjects LeFort I osteotomy with posterior maxillary impaction had been performed, 35 in monognathic and 80 in bignathic procedures. All 115 subjects received rigid fixation. For both females and males the minimum age was 18 in order to avoid errors caused by the influence of growth. A history of prior maxillofacial surgery, wire fixation, trauma, clefts and craniofacial syndromes were further exclusion criteria.

The sample size was calculated for a power of 0.8 at a significance level of 0.05 with Altman's nomogram [2]. As 15 patients were excluded because of unconfident landmark identification caused by insufficient radiograph quality, the study had a power of 0.78 at a significance level of 0.05 .

Table 1 Descriptive statistics of the 115 patients Tab. 1 Deskriptive Statistik der 115 Patienten

\begin{tabular}{lll}
\hline & Men & Women \\
\hline Patients total $(n)$ & 54 & 61 \\
Maxillary surgery $(n)$ & 15 & 20 \\
Bignathic surgery $(n)$ & 39 & 41 \\
Class II & 16 & 27 \\
Class III & 38 & 34 \\
Mean age at surgery (years) & 27 & 28 \\
Standard deviation of age (years) & 6 & 7 \\
Minimum age (years) & 18 & 18 \\
Maximum age (years) & 45 & 50 \\
\hline
\end{tabular}




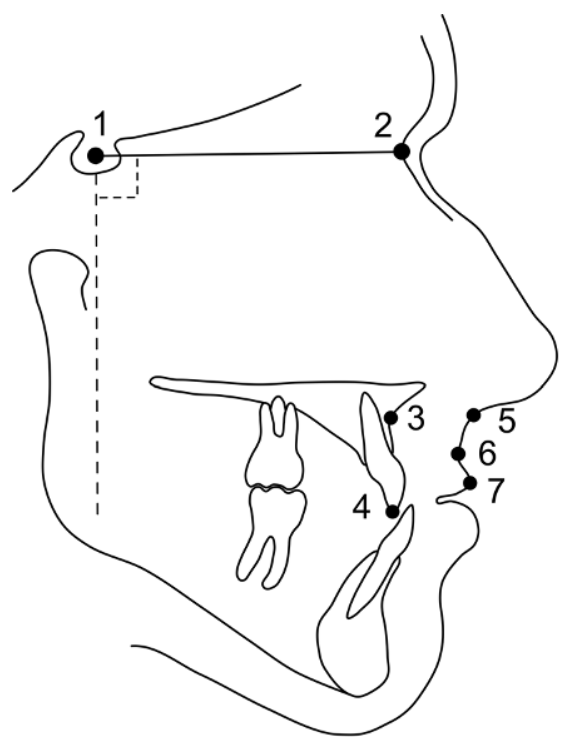

Fig. 1 Landmarks and reference lines used in this study: 1 sella; 2 nasion; 3 A point; 4 incision superius; 5 subnasale; 6 soft tissue A point; 7 labrale superius

Abb. 1 In der Studie verwendete Referenzpunkte und -linien. 1 Sella; 2 Nasion; 3 A-Punkt; 4 Incision superius; 5 Subnasale; 6 Weichgewebe-A-Punkt; 7 Labrale superius

For each subject a preoperative and a postoperative radiograph, taken at least 6 months after surgery, was selected. A Canon EOS 5D digital camera with a Canon compactmacro EF $50 \mathrm{~mm}$, f 1:2.5 lens (Canon Inc., Tokio, Japan) on a "copylizer eVision exe.cutive" camera stand (Kaiser Fototechnik GmbH \&Co. KG, Buchen, Germany) was used for the digitization process of the radiographs. One of the authors (S. R.) conducted a cephalometric analysis based on the method of Segner/Hasund [28] with the software DiagnoseFix 12.2006 (Dr. Jörg Wingberg, Buchholz, Germany).

On the basis of the analysis of Lines and Steinhauser [18] and Legan and Burstone [16] our cephalometric analysis was reduced to the examination of these relevant landmarks:

The soft tissue landmarks Sn (subnasale), $\mathrm{A}^{\prime}$ (soft tissue A) and Ls (labrale superius) and the corresponding hard tissue landmarks A (A point) and Is (incision superius) (Fig. 1). A coordinate system was designed to assess the surgical movement in the sagittal direction. NSL (nasionsella line) was used as the $\mathrm{x}$-axis, while the $\mathrm{y}$-axis was constructed as a line through the landmark sella, perpendicular to the NSL. This y-axis served as the vertical reference line for the examined landmarks.

We quantified the distance from the vertical reference line to each soft and hard tissue point and calculated the difference of the postsurgical minus the presurgical values.

The correlations between the shift in soft tissue landmarks $\left(\Delta \mathrm{Sn}, \Delta \mathrm{A}^{\prime}\right.$ and $\left.\Delta \mathrm{Ls}\right)$ and the shift in the corresponding hard tissue landmarks ( $\Delta \mathrm{A}$ and $\Delta \mathrm{Is})$ were then statistically analyzed. We conducted a bivariate linear re- gression analysis to determine the soft tissue profile changes related to surgical movement of the underlying hard tissue structures (R 3.1.2, R Foundation for Statistical Computing, Vienna, Austria).

\section{Results}

\section{Soft tissue A point}

Soft tissue A point changed minimum $-5.5 \mathrm{~mm}$ and maximum $9.7 \mathrm{~mm}$, while hard tissue A point changed minimum $-6.6 \mathrm{~mm}$ and maximum $10.7 \mathrm{~mm}$. The Shapiro-Wilk test showed normal distribution for displacements both in soft tissue A point $(p=0.53)$ and in hard tissue A point $(p=0.35)$. The Pearson correlation coefficient for soft tissue A point and hard tissue A point was 0.83 (Fig. 2a). The model to predict the change of soft tissue A point was soft tissue A point $=0.73 \times$ hard tissue A point with a coefficient of determination of $\mathrm{r}^{2}=0.69$ and a standard error of the estimate of $1.7 \mathrm{~mm}$.

\section{Subnasale}

Displacements of subnasale ranged from minimum $-5.2 \mathrm{~mm}$ to maximum $8.9 \mathrm{~mm}$ and were normally distributed according to the Shapiro-Wilk test $(p=0.42)$. The Pearson correlation coefficient for subnasale and hard tissue A point was 0.76 (Fig. 2b). Displacements in subnasale were predicted by the model Subnasale $=0.57 \times$ hard tissue A point . The coefficient of determination was $\mathrm{r}^{2}=0.58$ with a standard error of the estimate of $1.8 \mathrm{~mm}$.

\section{Labrale superius}

Labrale superius changed minimum $-7.2 \mathrm{~mm}$ and maximum $8.9 \mathrm{~mm}$, whereas incision superius changed minimum $-7.5 \mathrm{~mm}$ and maximum $10.7 \mathrm{~mm}$. Normal distribution of the displacements was indicated by a Shapiro-Wilk test for labrale superius $(p=0.47)$ and incision superius $(p=0.73)$. Pearson's correlation coefficient for labrale superius and incision superius was 0.81 (Fig. 2c). The prediction model of displacements for labrale superius was Labrale superius $=0.73 \times$ Incision superius with a coefficient of determination of $\mathrm{r}^{2}=0.66$ and a standard error of the estimate of $1.9 \mathrm{~mm}$.

The scatterplots (Fig. 2) show a linear correlation between each pair of landmarks, but with a wide spread for all three pairs. The residuals of the prediction models were symmetrically distributed without any recognizable pattern that would indicate another additional prediction variable (Fig. 3). 

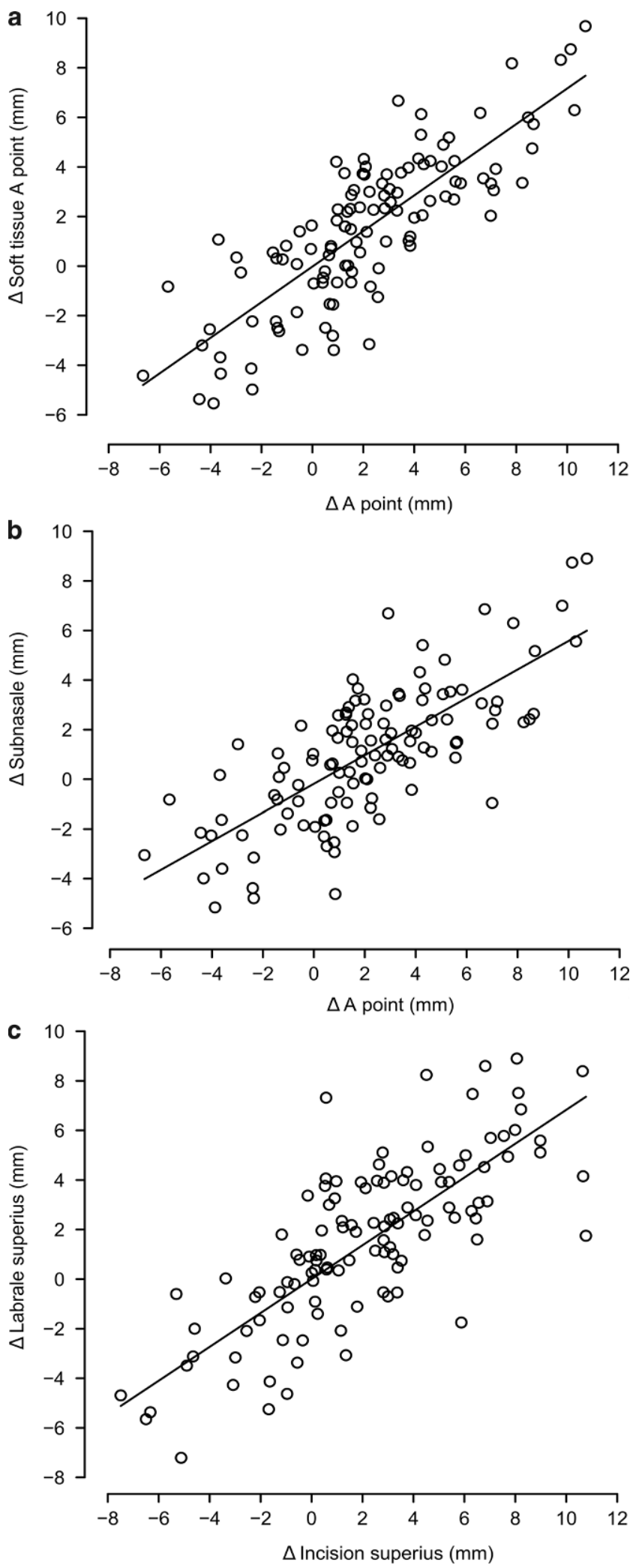

Fig. 2 Scatterplot and prediction model of sagittal changes for soft tissue A point (a), subnasale (b), and labrale superius (c)

Abb. 2 Streudiagramm und Vorhersagemodell der sagittalen Veränderungen für Weichgewebe-A-Punkt (a), Subnasale (b) und Labrale superius $(\mathbf{c})$
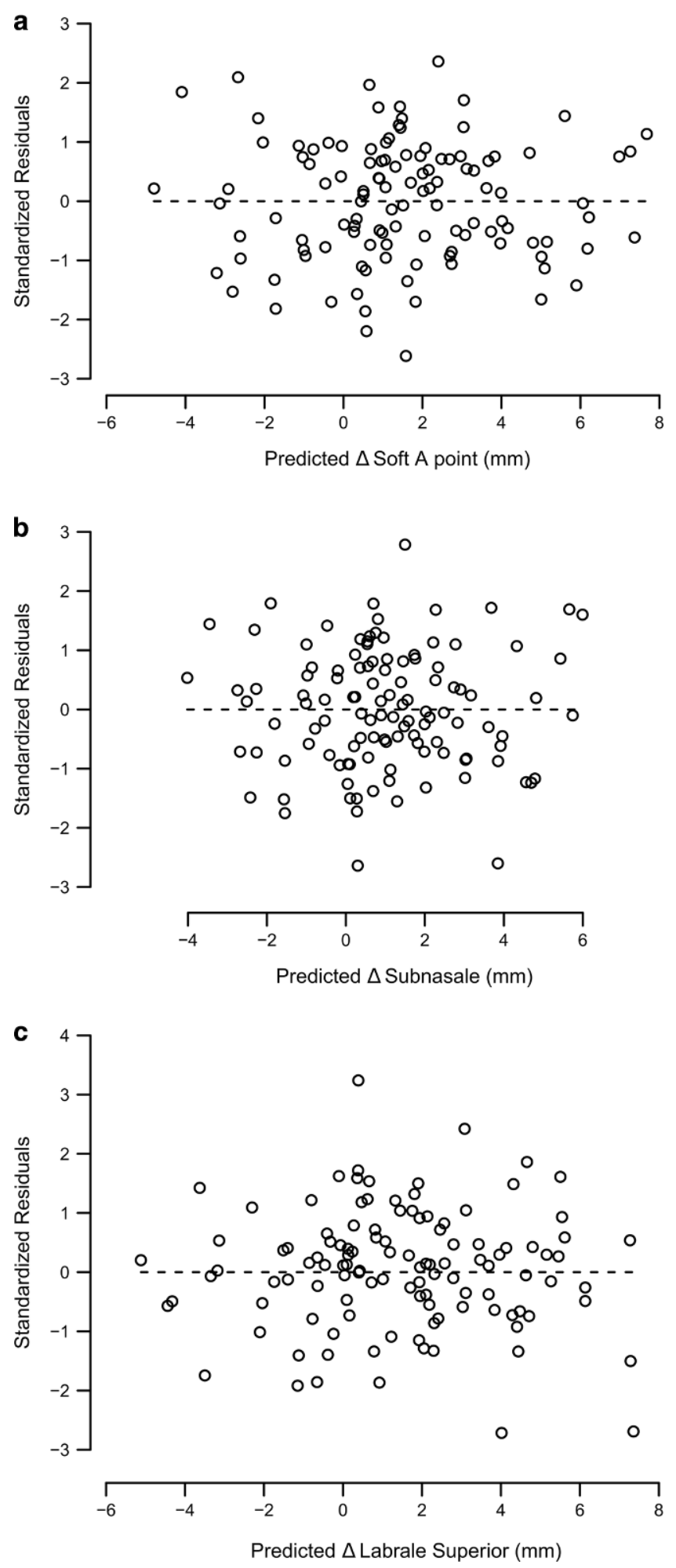

Fig. 3 Residual plots for predicted sagittal changes in soft tissue A point (a), subnasale (b), and labrale superius (c)

Abb. 3 Residuenplots für die prognostizierten sagittalen Veränderungen von Weichgewebe-A-Punkt (a), Subnasale (b) und Labrale superius (c) 


\section{Discussion}

Our results in this study for $\mathrm{A}^{\prime} / \mathrm{A}(73 \%), \mathrm{Sn} / \mathrm{A}(57 \%)$ and Ls/Is $(73 \%)$ correspond to many other studies [4-6, 17, $18,24]$. Some authors found results equal to ours by using slightly different methods, like for example different reference lines $[4,24,30]$. But there also exists a high variation of different results in literature [7, 8, 14, 15, 27]. The reasons that could be responsible for this high variance might be tonicity, posture, muscle pull and difficulty adopting a relaxed lip position during cephalogram exposure [22]. Another reason might as well be that the soft tissues follow the maxillary hard tissue structures in a relationship not as close as in the mandible [26] because the soft tissue of the upper lip is firmly connected to the base of the nose [18]. Furthermore, the lower lip also has an influence on the position of the upper lip. A surgical change of the position of the maxilla leads to a change of the position of the mandible and of the lower lip, both in bignathic and monognathic surgery.

It is apparent that maxillary soft tissue depends on a complexity of functional and anatomical influences, which might be the reason for our rather high prediction error of about $2 \mathrm{~mm}$, as well as the high variety of results in literature.

Although landmark localization on lateral cephalograms may be impaired by distortion or magnification [11], this two-dimensional method offers high reliability $[1,12]$.

Three-dimensional technologies can improve diagnostics providing a highly accurate reproduction of the facial morphology and even a very precise automatic cephalometry with exact landmark detection [13, 19]. However, our objective was to evaluate the ratio of the soft to hard tissue changes. The lateral cephalogram displays both hard and soft tissue structures in just one image, and that at a very low radiation exposure. Therefore, it was the medium of choice for our purpose. Furthermore, most clinicians simply do not have three-dimensional equipment, which still makes radiographs a widespread and valuable technique that should not be underestimated [26].

\section{Conclusions}

In this retrospective study we revealed a linear correlation between each pair of soft and hard tissue landmarks. But at the same time all three measurements demonstrated a wide distribution of measurement values. This outcome and also the mean prediction error of about $2 \mathrm{~mm}$ prompts a cautious use of postsurgical predictions of the maxillary-related soft tissue profile changes.
Funding Open Access funding enabled and organized by Projekt DEAL.

\section{Declarations}

Conflict of interest S. Rupperti, P. Winterhalder, S. Krennmair, S. Holberg, C. Holberg, G. Mast and I. Rudzki declare that they have no competing interests.

Ethical standards As a retrospective study, formal consent is not required.

Open Access This article is licensed under a Creative Commons Attribution 4.0 International License, which permits use, sharing, adaptation, distribution and reproduction in any medium or format, as long as you give appropriate credit to the original author(s) and the source, provide a link to the Creative Commons licence, and indicate if changes were made. The images or other third party material in this article are included in the article's Creative Commons licence, unless indicated otherwise in a credit line to the material. If material is not included in the article's Creative Commons licence and your intended use is not permitted by statutory regulation or exceeds the permitted use, you will need to obtain permission directly from the copyright holder. To view a copy of this licence, visit http://creativecommons.org/licenses/by/4. $0 \%$

\section{References}

1. Albarakati SF, Kula KS, Ghoneima AA (2012) The reliability and reproducibility of cephalometric measurements: a comparison of conventional and digital methods. Dentomaxillofac Radiol 41:11-17. https://doi.org/10.1259/dmfr/37010910

2. Altman DG (1980) Statistics and ethics in medical research: III how large a sample? Br Med J 281:1336-1338

3. Baherimoghaddam T, Tabrizi R, Naseri N, Pouzesh A, Oshagh M, Torkan S (2016) Assessment of the changes in quality of life of patients with class II and III deformities during and after orthodonticsurgical treatment. Int J Oral Maxillofac Surg 45:476-485. https:// doi.org/10.1016/j.ijom.2015.10.019

4. Becker OE, Avelar RL, Dolzan AN, Haas OL Jr., Scolari N, de Oliveira RB (2014) Soft and hard tissue changes in skeletal Class III patients treated with double-jaw orthognathic surgery-maxillary advancement and mandibular setback. Int J Oral Maxillofac Surg 43:204-212. https://doi.org/10.1016/j.ijom.2013.06.006

5. Chew MT (2005) Soft and hard tissue changes after bimaxillary surgery in Chinese Class III patients. Angle Orthod 75:959-963. https://doi.org/10.1043/0003-3219(2005)75[959:SAHTCA]2.0.CO;2

6. Chew MT, Sandham A, Wong HB (2008) Evaluation of the linearity of soft- to hard-tissue movement after orthognathic surgery. Am J Orthod Dentofacial Orthop 134:665-670. https://doi.org/10.1016/j. ajodo.2006.12.017

7. Coleta KE, Wolford LM, Goncalves JR, Pinto Ados S, Cassano DS, Goncalves DA (2009) Maxillo-mandibular counter-clockwise rotation and mandibular advancement with TMJ Concepts total joint prostheses: part IV-soft tissue response. Int J Oral Maxillofac Surg 38:637-646. https://doi.org/10.1016/j.ijom.2008.11.022

8. Conley RS, Boyd SB (2007) Facial soft tissue changes following maxillomandibular advancement for treatment of obstructive sleep apnea. J Oral Maxillofac Surg 65:1332-1340. https://doi.org/10. 1016/j.joms.2006.09.026

9. Fabre M, Mossaz C, Christou P, Kiliaridis S (2009) Orthodontists' and laypersons' aesthetic assessment of Class III subjects referred for orthognathic surgery. Eur J Orthod 31:443-448. https://doi.org/ 10.1093/ejo/cjp002 
10. Frost V, Peterson G (1991) Psychological aspects of orthognathic surgery: how people respond to facial change. Oral Surg Oral Med Oral Pathol 71:538-542. https://doi.org/10.1016/00304220(91)90357-i

11. Gribel BF, Gribel MN, Frazao DC, McNamara JA Jr., Manzi FR (2011) Accuracy and reliability of craniometric measurements on lateral cephalometry and 3D measurements on CBCT scans. Angle Orthod 81:26-35. https://doi.org/10.2319/032210-166.1

12. Hariharan A, Diwakar NR, Jayanthi K, Hema HM, Deepukrishna S, Ghaste SR (2016) The reliability of cephalometric measurements in oral and maxillofacial imaging: cone beam computed tomography versus two-dimensional digital cephalograms. Indian J Dent Res 27:370-377. https://doi.org/10.4103/0970-9290.191884

13. Holberg C, Heine AK, Geis P, Schwenzer K, Rudzki-Janson I (2005) Three-dimensional soft tissue prediction using finite elements. Part II: Clinical application. J Orofac Orthop 66:122-134. https://doi.org/10.1007/s00056-005-0422-7

14. Jakobsone G, Stenvik A, Espeland L (2012) Importance of the vertical incisor relationship in the prediction of the soft tissue profile after Class III bimaxillary surgery. Angle Orthod 82:441-447. https:// doi.org/10.2319/072911-475.1

15. Jokic D, Jokic D, Uglesic V, Macan D, Knezevic P (2013) Soft tissue changes after mandibular setback and bimaxillary surgery in Class III patients. Angle Orthod 83:817-823. https://doi.org/10. 2319/100112-775.1

16. Legan HL, Burstone CJ (1980) Soft tissue cephalometric analysis for orthognathic surgery. J Oral Surg 38:744-751

17. Lin SS, Kerr WJ (1998) Soft and hard tissue changes in Class III patients treated by bimaxillary surgery. Eur J Orthod 20:25-33

18. Lines PA, Steinhauser EW (1974) Soft tissue changes in relationship to movement of hard structures in orthognathic surgery: a preliminary report. J Oral Surg 32:891-896

19. Lippold C, Liu X, Wangdo K, Drerup B, Schreiber K, Kirschneck C, Moiseenko T, Danesh G (2014) Facial landmark localization by curvature maps and profile analysis. Head Face Med 10:54. https://doi.org/10.1186/1746-160X-10-54

20. Lovius BB, Jones RB, Pospisil OA, Reid D, Slade PD, Wynne TH (1990) The specific psychosocial effects of orthognathic surgery. J Craniomaxillofac Surg 18:339-342. https://doi.org/10.1016/ s1010-5182(05)80052-6
21. McNeill RW, Proffit WR, White RP (1972) Cephalometric prediction for orthodontic surgery. Angle Orthod 42:154-164. https://doi. org/10.1043/0003-3219(1972)042〈0154:CPFOS $\rangle 2.0 . C O ; 2$

22. Mobarak KA, Espeland L, Krogstad O, Lyberg T (2001) Soft tissue profile changes following mandibular advancement surgery: predictability and long-term outcome. Am J Orthod Dentofacial Orthop 119:353-367. https://doi.org/10.1067/mod.2001.112258

23. Pahkala RH, Kellokoski JK (2007) Surgical-orthodontic treatment and patients' functional and psychosocial well-being. Am J Orthod Dentofacial Orthop 132:158-164. https://doi.org/10.1016/j.ajodo. 2005.09.033

24. Park JU, Hwang YS (2008) Evaluation of the soft and hard tissue changes after anterior segmental osteotomy on the maxilla and mandible. J Oral Maxillofac Surg 66:98-103. https://doi.org/10. 1016/j.joms.2005.09.007

25. Robinson SW, Speidel TM, Isaacson RJ, Worms FW (1972) Soft tissue profile change produced by reduction of mandibular prognathism. Angle Orthod 42:227-235. https://doi.org/10.1043/00033219(1972)042 〈0227:STPCPB $\rangle$ 2.0.CO;2

26. Rupperti S, Winterhalder P, Rudzki I, Mast G, Holberg C (2018) Changes in the facial soft-tissue profile after mandibular orthognathic surgery. Clin Oral Investig. https://doi.org/10.1007/s00784018-2609-5

27. Rustemeyer J, Martin A (2013) Soft tissue response in orthognathic surgery patients treated by bimaxillary osteotomy: cephalometry compared with 2-D photogrammetry. Oral Maxillofac Surg 17:33-41. https://doi.org/10.1007/s10006-012-0330-0

28. Segner D, Hasund A (1998) Individualisierte Kephalometrie, 3rd edn. Segner, Hamburg

29. Steinhauser EW (1996) Historical development of orthognathic surgery. J Craniomaxillofac Surg 24:195-204

30. Wermker K, Kleinheinz J, Jung S, Dirksen D (2014) Soft tissue response and facial symmetry after orthognathic surgery. J Craniomaxillofac Surg. https://doi.org/10.1016/j.jcms.2014.01.032

Publisher's Note Springer Nature remains neutral with regard to jurisdictional claims in published maps and institutional affiliations. 